\title{
Outcrossing rate of Couratari multiflora (J.Smith) Eyma (Lecythidaceae), a low-density tropical tree species from a central Amazonian rainforest
}

\author{
Nadja LEPSCH-CUNHA ${ }^{1}$, Paulo Yoshio KAGEYAMA², Roland VENCOVSKY³, Henrique E. M. \\ NASCIMENTO ${ }^{4}$
}

\begin{abstract}
A multilocus mixed-mating model was used to evaluate the mating system of a population of Couratari multiflora, an emergent tree species found in low densities ( 1 individual/10 ha) in lowland forests of central Amazonia. We surveyed and observed phenologically 41 trees in an area of 400 ha. From these, only four mother trees were analyzed here because few of them set fruits, which also suffered high predation. No difference was observed between the population multilocus outcrossing rate $\left(t_{m p}=0.953 \pm 0.040\right)$ and the average single locus rate $\left(t_{s p=} 0.968 \pm 0.132\right)$. The four mother trees were highly outcrossed $\left(t_{m}-\right.$ 1). Two out of five loci showed departures from the Hardy-Weinberg Equilibrium (HWE) expectations, and the same results occurred with the mixed-mating model. Besides the low number of trees analyzed, the proportion of loci in HWE suggests random mating in the population. However, the pollen pool was heterogeneous among families, probably due to both the small sample number and the flowering of trees at different times of the flowering season. Reproductive phenology of the population and the results presented here suggest, at least for part of the population, a long-distance pollen movement, around 1,000 $\mathrm{m}$.
\end{abstract}

KEYWORDS: mating system, Couratari spp., genetic conservation, Amazon.

\section{Taxa de cruzamento de Couratari multiflora (J.Smith) Eyma (Lecythidaceae), uma espécie arbórea tropical de baixa densidade da Amazônia central}

\begin{abstract}
RESUMO
Foi utilizado um modelo de cruzamento misto multilocos para analisar o sistema de cruzamento de uma populaçáo de Couratari multiflora, espécie arbórea emergente encontrada em baixas densidades ( 1 indivíduo/10 ha) nas florestas de "terra firme" da Amazônia central. Inventariamos e observamos fenologicamente 41 árvores em uma área de 400 ha. Dessas, somente quatro árvores-mãe foram analisadas, pois poucas árvores produziram frutos, os quais também sofreram alta predação. Não foi observada diferença entre a taxa de cruzamento multilocos $\left(\mathrm{t}_{\mathrm{mp}}=0,953 \pm 0,040\right)$ e a taxa média de loco único $\left(\mathrm{t}_{\mathrm{sp}=} 0,968\right.$ $\pm 0,132)$. As quatro árvores-mãe apresentaram alta taxa de cruzamento $\left(t_{m}-1\right)$. Dois dos cinco locos analisados mostraram desvios das expectativas do Equilíbrio de Hardy-Weinberg (EHW), e os mesmos resultados ocorreram para o modelo misto de cruzamento. Apesar do baixo número de árvores analisadas, a alta proporção de locos em EHW sugere que a população tenha um sistema de cruzamento aleatório. Entretanto, o conjunto polínico foi heterogêneo entre famílias, provavelmente pelo pequeno número e florescimento das árvores analisadas em diferentes fases da estação de florescimento. A fenologia reprodutiva da população e os resultados apresentados neste estudo sugerem que ao menos parte da populaçáo cruza via movimento de pólen de longa distância, em torno de $1.000 \mathrm{~m}$.
\end{abstract}

PALAVRAS-CHAVE: taxa de cruzamento, Couratari spp., conservaçâo genética, Amazônia.

\footnotetext{
1 Instituto Nacional de Pesquisas da Amazônia. Inadja.nascimento@mct.gov.br;

2 Escola Superior de Agricultura Luiz de Queiroz/Universidade de São Paulo. kageyama@esalq.usp.br

${ }^{3}$ Escola Superior de Agricultura Luiz de Queiroz/Universidade de São Paulo. vencovsky@esalq.usp.br

${ }^{4}$ Instituto Nacional de Pesquisas da Amazônia. hnasci@gmail.com
} 


\section{INTRODUCTION}

Many tropical tree species occur in low densities (Hubbell and Foster, 1986; Clark and Clark, 1996; Oliveira and Mori, 1999; Condit et al., 2002), hence there is an important need to understand their genetic structure and mating system in order to ensure their conservation. Studies conducted on low-density species have revealed a mixed to predominant, or complete outcrossing mating system, typically coupled with low genetic differentiation among the populations (Hamrick and Murawski, 1990; Murawski and Hamrick, 1991; Murawski, 1995; Nason and Hamrick, 1997; Lepsch-Cunha et al., 2001). However, the great majority of these studies were developed in relatively small areas and with samples of adult trees, and not with localization of all adult trees continuously inventoried.

In this paper, we report results on the mating system of Couratari multiflora, a large tree species found in lowland forests of central Amazonia at low densities (1 tree per each $10 \mathrm{ha})$. It is probably an uniformly low-density species throughout its geographical range, as the available information on its abundance in other locations shows (Mori and cols., 1987; Mitchel and Mori, 1987). In a previous work on the species, we found high genetic diversity for both seedling and adult trees when compared to other tropical trees (LepschCunha et al., 1999). In a primary forest, we located all adult $s$ in an area of 400 (ha) continuously, which permitted the monitoring of their phenological behavior at the population level (Lepsch-Cunha and Mori, 1999). The resulting data coupled with the estimated outcrossing rate provided us with an understanding of the mating system of this species. Our objectives here are to estimate the outcrossing rate, to test the assumptions of the mixed-mating system model of Ritland and Jain (1981), and to contribute to the understanding of rare species and its biological conservation implications.

\section{MATERIAL AND METHODS}

\section{THE STUDIED SPECIES}

Couratari multiflora (J.Smith) Eyma (Lecythidaceae) occurs from Venezuela throughout the Guianas and the Brazilian Amazon (Mori and Prance, 1990). This species is represented by emergent trees reaching 40-50 m in height, which possess winged seeds dispersed by the wind (Mori and Lepsch-Cunha, 1995). The flower is zygomorphic and is visited by few, specialized pollinators, such as large euglossine bees (Mori et al., 1980; Mori and Boeke, 1987). The wood is known as "tauari" and is harvested extensively for timber.

\section{DATA COLECTION}

Field work was conducted in a 10,000-ha reserve, nominated Reserve 1501, inside a continuous primary forest of the Biological Dynamics of Forest Fragments Project (BDFFP), located about $90 \mathrm{~km}$ north of Manaus (Amazon, Brazil, 2o 30' S, 60 W) (Bierregaard and Gascon, 2001). Initially, we searched continuously for all trees considered adults or with $\mathrm{DBH} \geq 20.0 \mathrm{~cm}$ in an area of 400-ha, resulting in 41 trees, and with a density of 0.106 ind./ha (Figure 1). During one reproductive season (Nov 1992 to December 1993), all of them were phenologically observed, resulting in a low production of mature fruits. The population flowered from January to June, with a peak in the mid-wet season (March), and fruits during the dry season, from May to September. Twenty seven trees out 41 flowered, and from these 27 , nine were seen bearing just immature fruits, which were highly predated by animals, and nine bore mature ones (Lepsch-Cunha and Mori, 1999). Out of these nine maturefruited trees, only four seed families (progenies) were sampled, also as consequence of a high predation of fruits by monkeys and macaws. Summing up to this, each of these four trees flowered in different times of flowering season, i.e., in the beginning, peak and end. Even considering the statistical problems imposed by these limitations, which are indicated and commented throughout the results, the phenological population study made before brought strong information that were summed here, considering the urgency to bring biological results about very low density tropical tree species.

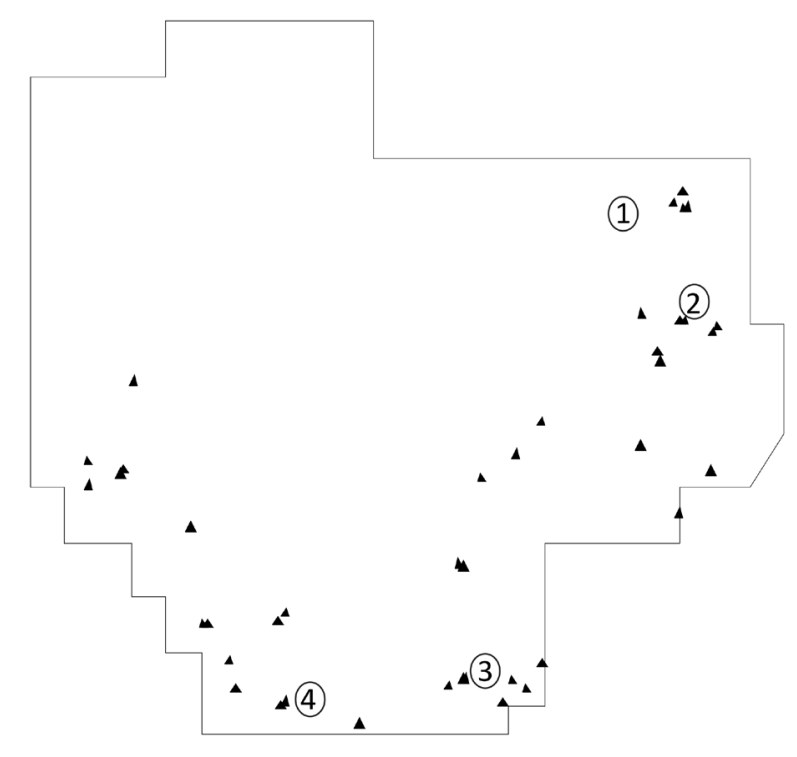

Figure 1 - Spatial distribution of the 41 trees (black triangles) and four studied C. multiflora trees (numbers inside the circles) in the Reserve 1501 of the Biological Dynamics of Forest Fragments Project, $90 \mathrm{~km}$ north from Manaus, Amazon, Brazil. 
Enzyme extracts were made from leaves of an average of 25 seedlings per mother-tree (Table 3), using the complete extraction buffer of Liriodendron sp. (Alfenas et al., 1991). The horizontal electrophoresis run was performed with penetrose gel at a concentration of $13 \%$ in the Universidade de São Paulo (USP/ESALQ) laboratory in Piracicaba city, State of São Paulo, Brazil. Histidine pH 7.0 with $4 \%$ sucrose (Brown et al., 1975) and morpholine-citrate $\mathrm{pH} 6.1$ (Clayton and Tretiak, 1972) buffers were used, allowing us to interpret 5 enzyme systems: malate dehydrogenase (MDH - EC 1.1.1.37), phosphoglucoisomerase (PGI - EC 5.3.1.9), phosphoglucomutase (PGM - EC 5.4.2.2), peroxidase (PRX - EC 1.11.1.7), and shikimic dehydrogenase (SKDH - EC 1.1.1.25). Enzyme stain recipes were used as described by Murphy et al. (1990), Soltis and Soltis (1990) and Alfenas et al. (1991), and three replicates were made for each tree assayed.

\section{DATA ANALYSIS}

We used MLTR software of Ritland (Version 1996), based on the mixed mating model (Clegg, 1980; Ritland and Jain, 1981; Brown et al. 1984). From progeny array data, we estimated: 1. the multilocus outcrossing rate for the population $\left(\mathrm{t}_{\mathrm{mp}}\right)$ and families $\left(\mathrm{t}_{\mathrm{m}}\right)$, by the Newton-Raphson method, 2 . the single locus outcrossing rate, $t_{s}$, and its average for all loci, $t_{s p}$, which was calculated as the arithmetic mean of all $t_{s}$ values, 3. the ovule (o) and pollen (p) allele frequencies, which were obtained by the expectation maximization method, 4. the variances through the bootstrap technique (1000 bootstraps used), and 5. the mother genotypes. For the calculation of the multilocus outcrossing rate of the individual trees $\left(\mathrm{t}_{\mathrm{m}}\right)$ and its variances, we held the population allele frequencies constant. Departure from the model's assumptions was tested for each locus through Chi-square goodness-of-fit tests made by the MLT program of Ritland (1990). Chi-square or exact-Fisher tests (Swofford and Selander, 1989) were used to test whether genotype numbers in the progeny arrays departed significantly from Hardy-Weinberg Equilibrium proportions, as expected if mating was not at random. We tested the differences between the ovule and pollen allele frequencies' contributions to the seed gene pool through the Chi-square statistic, $c^{2}=$ $N F_{S T}(k-1)$, with $(k-1)$ degrees of freedom, in which $N$ is the number of gametes in the pollen and ovule group, and $k$ is the number of alleles. In this case, the Wright's $F_{S T}(1965)$ is being used as a measure of genetic diversity between pollen and ovule pools, and, as in the next case, these pools are being treated as separate subpopulations. We tested the assumption of the homogeneity of the pollen pool in the population that contributed to seedling genotypes of different mother trees through Chi-square tests, as suggested by Murawski and Hamrick (1991). Treating each family as a subpopulation and using their $F_{S T}$ 's, we examined among family diversities in the pollen allele frequencies that contributed to the gene pool of seeds. One $F_{S T}$ value was calculated for each locus based on $F_{S T}=\sigma^{2} /\left[p_{i}\left(1-p_{i}\right)\right]$, where $\sigma^{2}$ is the variance in pollen allele frequencies among seed tree families, and $p_{i}$ is the frequency of the $\mathrm{i}^{\text {th }}$ pollen allele averaged over all mother trees. The tests of significance for the $F_{S T}$ values were made using Chi-square statistics suggested by Workman and Niswander (1970), namely $c^{2}=2 S F_{S T}(k-1)$ with $[(k-1)(s-1)]$ degrees of freedom, where $k=$ the allele number, $s=$ the number of subpopulations (or families), and $S=$ the total number of seedlings.

\section{RESULTS}

\section{GENETIC INTERPRETATIONS}

From the five enzyme systems assayed, we used five loci to estimate outcrossing rates, and seven loci for the other parameters (see explanation thereafter). From seven loci, all were polymorphic. The criteria used for a locus to be considered polymorphic was an allele frequency of $1 \%$ or more. Malate dehydrogenase $(\mathrm{MDH})$ presented three banding regions, the two external ones, Mdh-1 and Mdh-3, were considered as individual loci and exhibited a dimeric pattern, with three alleles in both loci. Phosphoglucoisomerase (PGI) exhibited two banding regions, but only the slower was interpretable, dimeric and with four alleles. Phosphoglucomutase (PGM) exhibited two banding regions, considered as two monomeric loci, Pgm-1 and Pgm-2, with five alleles. Peroxidase (PRX) presented three banding regions, the two external ones distinctly as monomeric loci, but the center zone, although not entirely interpretable, appeared to be represented by more than one locus, only Prx-3 showed good staining in most seedlings, with three alleles. Shikimic dehydrogenase (SKDH) exhibited a duplicated monomeric pattern, as described by Weeden and Gottlieb (1980), with lighter duplication bands (ghost bands), which were rejected in the interpretation, the darker banding zone was interpreted as a monomeric locus with 3 alleles. All enzymes, except for peroxidase (PRX), were indifferent or showed better resolution utilizing the complete extraction buffer of Liriodendrum (with MTT and mercaptoethanol). PRX showed interpretable staining only without mercaptoethanol, being negatively affected by concentrations larger than $3 \%$ of hydrogen peroxide. Using PGM and SKDH without mercaptoethanol and MTT impaired the staining. 
Table 1 - Maximum likelihood estimates of the gene frequencies in the pollen and the ovule pools in progeny arrays of four $C$. multiflora trees in Central Amazonia, and corresponding $\mathrm{c}^{2}$ heterogeneity tests, $F_{S T}$ is being used as a measure of genetic diversity between these two gametic pool (see text for details).

\begin{tabular}{|c|c|c|c|c|c|c|}
\hline Locus & $\mathrm{S}^{\mathrm{a}}$ & Allele & $\begin{array}{c}\text { Pollen pool } \\
\text { (SD) }^{c}\end{array}$ & $\begin{array}{l}\text { Ovule pool } \\
\text { (SD) }\end{array}$ & $\mathrm{F}_{\mathrm{ST}}{ }^{\mathrm{d}}$ & $c^{2}$ \\
\hline \multirow[t]{3}{*}{ Mdh-1 } & 103 & 1 & $0.640(0.047)$ & $0.625(0.047)$ & & \\
\hline & & 2 & $0.355(0.047)$ & $0.375(0.047)$ & & \\
\hline & & 3 & $0.005(0.007)^{b}$ & 0.000 & 0.0003 & 0.0745 \\
\hline \multirow[t]{3}{*}{ Mdh-3 } & 103 & 1 & $0.897(0.029)$ & 1 & & \\
\hline & & 2 & $0.052(0.021)$ & 0.000 & & \\
\hline & & 3 & $0.052(0.021)$ & 0.000 & 0.0400 & $8.57^{\star}$ \\
\hline \multirow[t]{3}{*}{ Pgi-1 } & 103 & 1 & $0.451(0.049)$ & $0.500(0.049)$ & & \\
\hline & & 2 & $0.364(0.047)$ & $0.250(0.042)$ & & \\
\hline & & 3 & $0.185(0.038)$ & $0.250(0.042)$ & 0.0078 & 1.66 \\
\hline \multirow[t]{3}{*}{ Pgm-1 } & 95 & 1 & $0.605(0.050)$ & $0.625(0.049)$ & & \\
\hline & & 2 & $0.338(0.048)$ & $0.250(0.044)$ & & \\
\hline & & 3 & $0.057(0.023)$ & $0.125(0.033)$ & 0.0061 & 1.30 \\
\hline \multirow[t]{3}{*}{ Pgm-2 } & 102 & 1 & $0.781(0.041)$ & $0.875(0.032)$ & & \\
\hline & & 2 & $0.042(0.019)$ & $0.125(0.032)$ & & \\
\hline & & 3 & $0.177(0.037)$ & 0.000 & 0.0393 & $8.40 *$ \\
\hline \multirow[t]{3}{*}{ Prx-2 } & 99 & 1 & $0.718(0.045)$ & $0.750(0.043)$ & & \\
\hline & & 2 & 0276(0.044) & $0.250(0.043)$ & & \\
\hline & & 3 & $0.005(0.007)^{b}$ & 0.000 & 0.0011 & $0.24 \mathrm{~ns}$ \\
\hline \multirow[t]{3}{*}{ Skdh-1 } & 103 & 1 & $0.247(0.042)$ & $0.625(0.047)$ & & \\
\hline & & 2 & $0.343(0.046)$ & $0.250(0.042)$ & & \\
\hline & & 3 & $0.410(0.048)$ & $0.125(0.032)$ & 0.0895 & $19.14^{\star *}$ \\
\hline
\end{tabular}

a $\mathrm{S}=$ number of seedlings.

b immigrant allele absent in the adult population.

' SD = standart deviation.

genetic diversity between ovule and pollen pool
$* \mathrm{P}<0.05, * \star \mathrm{P}<0.01$

\section{MIXED MATING MODEL ASSUMPTIONS}

Estimates of allele frequencies attributed to the pollen and ovules in the gene pool of seedlings showed significant difference at $\mathrm{P}<0.01$ for Skdh-1, followed by Mdh-3 and Pgm- 2 at $\mathrm{P}<0.05$. These differences could be attributed to: 1 . relative differences in male and female contribution among trees, 2. immigrant pollen to the sampled population, 3. selection between the pollination time and the seedling sample, or 4 . the lack of a representative sample of mother trees (Ritland and Jain, 1981). The allelic frequencies of the Mdh-3 and Pgm-2 loci showed the presence of pollen alleles that are not present in the ovule pool (in bold at Table 1). However, these pollen alleles were present in the adult population ( 400 ha) with a representative frequency as shown by Lepsch-Cunha et al. (1999). Therefore, the significant differences are not explained by the presence of immigrant pollen to the sampled population, but probably by the presence of these pollen alleles in the pollen donor population, which were absent in the pollen pool of mother trees. Immigrant alleles to the total population (seedlings and adults) were encountered in the seedling population at other loci (Mdh-1 and Prx-2), but not in Skdh-1, Mdh-3 and Pgm-2. The significant differences probably are due to the low number of mother trees sampled. The seedling population presented a majority of loci $(72 \%)$ in Hardy-Weinberg Equilibrium (HWE) expectations, with the exception of the Pgi-1 and the Skdh-1 loci (Table 3), indicating that the observed frequencies for some loci did not diverge significantly from the Hardy-Weinberg's model expected frequencies. These results are not expected because both the differences in male and female contribution among trees and the selection between the pollination time and the seedling sample may occur. The expectation in these cases would be greater departures from the HWE. The pollen pool in the population resulted in significant differences among families ( $\mathrm{P}<0.01)$ for all loci, but Pgm-2 (Table 2). Therefore, the mother trees are receiving a differentiated pollen pool from the population. 
Table 2 - Pollen allele frequencies and $c^{2}$ tests for verification of departures from pollen pool homogeneity received by each mother trees. The $F_{S T}$ stastistics is being used as a measure of genetic diversity, considering families (progeny arrays) as subpopulations.

\begin{tabular}{|c|c|c|c|c|c|c|c|}
\hline Locus & Allele & Family 1 & Family 2 & Family 3 & Família 4 & Media $n$ & $\mathrm{~F}^{\mathrm{b}}$ \\
\hline \multirow[t]{3}{*}{ Mdh-1 } & 1 & 0.790 & 0.750 & 0.330 & 0.310 & 0.545 & \\
\hline & 2 & 0.180 & 0.250 & 0.670 & 0.690 & 0.448 & \\
\hline & 3 & 0.030 & 0.000 & 0.000 & 0.000 & 0.008 & $0.210^{* * *}$ \\
\hline \multirow[t]{3}{*}{ Mdh-3 } & 1 & 0.970 & 0.870 & 0.840 & 0.930 & 0.903 & \\
\hline & 2 & 0.000 & 0.000 & 0.160 & 0.070 & 0.058 & \\
\hline & 3 & 0.030 & 0.130 & 0.000 & 0.000 & 0.040 & $0.054^{* *}$ \\
\hline \multirow[t]{3}{*}{ Pgi-1 } & 1 & 0.390 & 0.200 & 0.880 & 0.080 & 0.388 & \\
\hline & 2 & 0.370 & 0.550 & 0.120 & 0.800 & 0.460 & \\
\hline & 3 & 0.240 & 0.250 & 0.000 & 0.110 & 0.150 & $0.271^{* * *}$ \\
\hline \multirow[t]{3}{*}{ Pgm-1 } & 1 & 0.830 & 0.660 & 0.340 & 0.680 & 0.628 & \\
\hline & 2 & 0.140 & 0.250 & 0.660 & 0.210 & 0.315 & \\
\hline & 3 & 0.030 & 0.090 & 0.000 & 0.110 & 0.058 & $0.150 * * *$ \\
\hline \multirow[t]{3}{*}{ Pgm-2 } & 1 & 0.780 & 0.810 & 0.880 & 0.790 & 0.815 & \\
\hline & 2 & 0.010 & 0.030 & 0.000 & 0.070 & 0.028 & \\
\hline & 3 & 0.210 & 0.160 & 0.120 & 0.140 & 0.158 & 0.011 \\
\hline \multirow[t]{3}{*}{ Prx-1 } & 1 & 0.960 & 0.590 & 0.640 & 0.750 & 0.735 & \\
\hline & 2 & 0.040 & 0.410 & 0.032 & 0.250 & 0.255 & \\
\hline & 3 & 0.000 & 0.000 & 0.040 & 0.000 & 0.010 & $0.099 * * *$ \\
\hline \multirow[t]{4}{*}{ Skdh-1 } & 1 & 0.110 & 0.330 & 0.090 & 0.330 & 0.215 & \\
\hline & 2 & 0.590 & 0.060 & 0.290 & 0.670 & 0.403 & \\
\hline & 3 & 0.300 & 0.610 & 0.620 & 0.000 & 0.383 & $0.213^{* * *}$ \\
\hline & & & & & & $\mathrm{F}_{\text {STmed }}{ }^{\mathrm{a}}$ & 0.144 \\
\hline
\end{tabular}

${ }^{\text {a }} F_{\text {STmed }}=F_{\text {ST }}$ averaged;

${ }^{\mathrm{b}}$ diversity among families

$\star \star P<0.01 ; * \star * * P<0.001$

\section{ESTIMATES OF OUTCROSSING RATES}

We found departures from the mixed-mating model in two (Pgi-1, Skdh-1) of seven loci (Table 3, the estimates of outcrossing rates used just five loci, see below). These departures have had little effect on the estimates when using multilocus methods to obtain outcrossing rates as pointed out by Ritland (1983) and Brown et al. (1984). We rerunning the data without these significant loci, and neither the outcrossing rate nor other parameters were noticeably altered. In consideration of the small number of families in this study, we first ran the single locus program to verify the convergence in the likelihood maximization estimates for each locus in the different families. The only locus without a convergence in the likelihood maximization estimates was Mdh-1. Furthermore, from seven loci initially analyzed, two (Mdh-1 and Pgm-2) showed family outcrossing rates without convergence of $t$-estimates $(t \geq 2)$. Therefore, these two loci were eliminated from our calculations of the average single locus outcrossing rate $\left(\mathrm{t}_{\mathrm{sp}}\right)$ and also the population multilocus rate $\left(\mathrm{t}_{\mathrm{mp}}\right)$. Both averaged single locus $\left(\mathrm{t}_{\mathrm{sp}}\right)$ and multilocus $\left(\mathrm{t}_{\mathrm{mp}}\right)$ estimates of the outcrossing rate were close to one. As suggested by Brown et al. (1984), values of $\mathrm{t}>1$ (or 100 percent) are due to a failure of the model to deal with multiple heterozygous mother genotypes, rather than disassortative mating per se, or due to the invalidity of the mixed-mating model. Murawski and Hamrick (1992b) also pointed out that these $t$ values $>1$ are statistically valid estimates. We found single locus outcrossing estimates $\left(\mathrm{t}_{\mathrm{s}}\right.$ ) ranged from 0.48 to 1.00 , being very different from locus to locus (Table 3). This range has been also shown in many studies (Shaw and Allard, 1981; Ritland and ElKassaby, 1985). For isozyme markers, Brown et al. (1984) discussed the possible factors contributing to this problem, and concluded that this heterogeneity of estimates over loci may not necessarily argue that the single loci estimation, or the mixed-mating model are unsatisfactory. All individual-family multilocus outcrossing estimates also resulted in values of $\mathrm{t}_{\mathrm{m}}$ $=1.00$ (Table 3$)$. The expected variance among the families of outcrossing estimates calculated by the program was zero. It is noteworthy that when the run was conducted with less than 4 loci in any combination this variance and the nonconvergence of $t$ estimates began to appear. 
Table 3 - The single locus $\left(t_{s}\right)$ and the multilocus outcrossing rates of the individual trees $\left(t_{m}\right)$ of $C$. multiflora. Probabilities of goodness of fit tests for HardyWeinberg Equilibrium expectations ( $\left.\mathrm{PX}^{2}\right)$ and $\mathrm{c}^{2}$ fit tests for multilocus mixed mating model are given, both for individual loci.

\begin{tabular}{|c|c|c|c|c|c|c|}
\hline Locus & $\begin{array}{l}P^{2} \\
\text { (HWE) }\end{array}$ & $\begin{array}{c}\mathrm{c}^{2} \\
\text { (mixed mating model) }\end{array}$ & $\mathrm{t}_{\mathrm{s}}(\mathrm{SE})$ & $\begin{array}{l}\text { Individual } \\
\text { mother tree }\end{array}$ & No. of seedlings & $\mathrm{t}_{\mathrm{m}}(\mathrm{SE})$ \\
\hline Mdh-3 & 1.000 & 0.000 & $0.480(0.195)$ & 1 & 30 & $1.135(0.076)$ \\
\hline Pgi-1 & 0.000 ** & 45.25 ** & $1.313(0.099)$ & 2 & 30 & $1.116(0.075)$ \\
\hline Pgm-1 & 1.000 & 2.222 & $0.970(0.108)$ & 3 & 27 & $1.019(0.076)$ \\
\hline Prx-2 & 0.878 & 9.551 & $1.478(0.148)$ & 4 & 16 & $1.032(0.103)$ \\
\hline Skdh-1 & $0.004 * *$ & $39.77^{* *}$ & $0.598(0.086)$ & & & \\
\hline Mdh-1 & 0.679 & 0.044 & not used & & & \\
\hline Pgm-2 & 0.528 & 7.848 & not used & & & \\
\hline $\mathrm{t}_{\mathrm{s}}(\mathrm{SE})$ & & & $0.968(0.132)$ & $\mathrm{t}_{\mathrm{m}}(\mathrm{SE})$ & & $0.953(0.040)$ \\
\hline
\end{tabular}

\section{DISCUSSION}

The C. multiflora mating system analysis showed multilocus outcrossing rates of individual mother trees and of the population equal to one. Two out of five loci showed significant deviations from the mixed mating model and also from the Hardy-Weinberg Equilibrium (HWE) expectations, indicating random mating in this population. The contribution of male and female gametes to the seed pool was homogenous, with the exception of one locus $(\mathrm{P}<0.05)$. Nevertheless, the pollen pool was differentiated among families, with mother trees receiving a differentiated pollen pool from the population.

Clegg (1980) suggested that spatial heterogeneity in pollen allele frequencies could be due to the family structure in the population. However, the proportion of loci in HWE, the homogeneity of pollen and ovule allele frequency distributions within families, and the population phenological study observations made in the same year as the seed collection was undertaken (Lepsch-Cunha and Mori, 1999), gave rise to a different explanation. This pollen pool heterogeneity appears to be a consequence of (i) the seed sampling period of each analyzed mother-tree within a long flowering season (6 months, at the beginning, peak, and end of the flowering season), (ii) the smaller number of flowered trees and their greater spatial clustering at the end of the flowering season, represented by two of four families under study, (iii) the small number of families analyzed, and (iv) the variation in the flowering time of each mother-tree.

The phenological monitoring of 41 surveyed trees showed a tendency for early and late trees to flower for longer periods of time ( $-45-60$ days $)$ than peak-flowering trees $(-15$ days) (Lepsch-Cunha and Mori, 1999). This flowering-time variation in the population promoted a greater phenological flowering overlap than had been supposed by the long, annual flowering season. These features conferred some similarity in the number of possible pollen donors during the whole flowering season, with the exception of the late trees. In this period, the number of flowered trees decreased and they were in general closer or more aggregated, differently from the early and peak trees. Two of four mother-trees (\#3 and \#4) analyzed here flowered during the late flowering season, the tree \#4 being one of the last in the population to flower. These patterns can be seen in the differences among progeny arrays: the mother-tree \#1 did not possess 2 of 21 pollen alleles, whereas trees \#2, \#3 and \#4 lacked 3, 4 and 5 of them, respectively (Table 2). Therefore, deviations from some assumptions of the mixed mating model appear to be a consequence of outcrossing among few, and close trees at the end of the flowering season, which does not corroborate family structuring. Furthermore, although the reproductive phenology showed that there was a relatively similar number of trees flowering at any time during the long flowering season, the reproductive-tree assemblage varied throughout the whole season. All individual-family multilocus outcrossing estimates also resulted in values of $\mathrm{t}_{\mathrm{m}}=1.00$ (Table 3 ). This reveals that regardless of the flowering period of seed collection (early, peak and late flowering season), these four mother trees outcrossed completely, or selfed seeds were aborted (selection before the sampling collection).

Lepsch-Cunha and Mori (1999) calculated that the majority of synchronic flowering trees of $C$. multiflora studied here were 600-1000 m distant of each other during the flowering season. The apparently aggregated spatial pattern of some trees (Figure 1) did not correspond to that of synchronic flowering trees, the latter being much more widely spaced. 
The small values of third quartiles (or deviations from median in smaller distances) reflected a low probability of mating between neighbors. These results, coupled with the complete outcrossing rates in different families throughout the long flowering season, suggest that most mating probabilities in these four mother-trees occurred between distant trees, except at the end of the flowering season. This result is shared with many other tropical tree species studied to date, whose distances as long as $3 \mathrm{~km}$ or more among trees are not an obstacle to pollen flow and effective outcrossing (Gandara 1996, Nason and Hamrick 1997, Aldrich and Hamrick 1998, White et al. 1998, Dick 2001, Ghazoul and McLeisch 2001).

Indeed, the majority of tropical low-density tree species have shown predominant to complete outcrossing rates (i.e. $\mathrm{T}_{\mathrm{m}}>=0.85$ ) (O'Malley and Bawa, 1987; Murawski and Hamrick, 1991; Gandara, 1996, Stacy et al., 1996; Sebbenn et al., 2000, see also Tables in Murawski, 1995; Nason and Hamrick, 1997; Lepsch-Cunha et. al., 2001). Exceptions are restricted to some families, i.e. Bombacaceae (Murawski et al., 1990, 1992a; Murawski and Hamrick, 1992b; Gribel et al., 1999), and to populations that suffered decreasing numbers of individuals or area, as tree thinning and forest fragmentation, which have shown mixed mating systems $(\leq 0.8)$ (review in Lepsch-Cunha et al., 2001).

\section{CONCLUSION}

The Couratari multiflora trees analyzed here outcrossed at rates equal to $100 \%$ and flowered during a reproductive season when flowered trees in the population were distant from each other among 600 to $1000 \mathrm{~m}$. These results support the assumption that this species is pollinated by pollinators travelling distances as far as $1,000 \mathrm{~m}$. The constancy of complete outcrossing rates in trees collected in different periods of a relative long flowering season and in different flowering densities suggests that this species has a high probability to have some mechanism of self-incompatibility. If not, the selection favoring outcrossed seeds is very possible. Understanding the relationship between genetic and ecological/demographic parameters will help to make appropriate guidelines for management and conservation practices to be developed.

\section{ACKNOWLEDGEMENTS}

We are especially grateful to Romeu Cardoso, Antônio Ribeiro, Paulo Apóstolo and Angela Imakawa for field assistance, to Weber do Amaral for his very helpful revision of the manuscript. We also thank Chris Dick for his comments. This research was supported by the Biological Dynamics of Forest Fragments Project, a Smithsonian Institution and Instituto Nacional de Pesquisas da Amazônia
(INPA) cooperation, Conselho Nacional de Pesquisas e Desenvolvimento Tecnológico (CNPq) of Brazil and Margaret Mee Foundation. This paper is the contribution \# 454 in the BDFFP technical series.

\section{BIBLIOGRAPHY}

Alfenas, A.C.; Peters, I.; Brune, W.; Passador, G.C. 1991. Eletroforesy of proteins and isoenzyms for fungi and forest tree species. Imprensa Universitária, Universidade Federal de Viçosa, Viçosa, MG, Brasil, 78 pp. (in Portuguese)

Aldrich, P.R.; Hamrick, J.L. 1998. Reproductive dominance of pasture trees in a fragmented tropical forest mosaic. Science, 281: 103-105.

Bierregaard, R.O. Jr; Gascon, C. 2001. The Biological Dynamics of Forest Fragments Project: Overview and History of a LongTerm Conservation Project. In: Bierregaard, R.O. Jr; Gascon, C.; Lovejoy, T.E.; Mesquita, R. (Eds.). Lessons from Amazonia: The Ecology and Conservation of a Fragmented Forest. Yale University Press, Chicago, p. 5-12.

Brown, A.H.D.; Barrett, S.C.H.; Moran, G.F. 1984. Mating system estimation in forest trees: models, methods and meanings. In: Gregorius, H.R. (Ed.) Population genetics in forestry. SpringerVerlag, Berlin, p. 32-49.

Clark, D.B.; Clark, D.A. 1996. Abundance, growth , and mortality of very large trees in Neotropical lowland rain forest. Forest Ecology and Management, 80: 235-244.

Clayton, J.; Tretiak, D. 1972. Amine-citrate buffers for $\mathrm{pH}$ control in starch gel electrophoresis. Journal of Fisheries Research Board Canadian, 29: 1169-1172.

Clegg, M.T. 1980. Measuring plant mating systems. Bioscience, 30: 814-818

Condit, R.; Pitman, N.; Leigh, E.G.; Chave, J.; Terborgh, J.; Foster, R.B.; Núñez, P.V.; Aguilar, S.; Valencia, R.; Villa, G.; MullerLandau, H.; Losos, E.; Hubbell, S.P. 2002. Beta-diversity in tropical forest trees. Science, 295: 666-669.

Dick, C.W. 2001. Genetic rescue of remnant tropical trees by an alien pollinator. Proceedings of Royal Society of London, 268: 2391-2396.

Gandara, F.B. 1996. Genetic Diversity, outcrossing rate, and genotypes spatial structure of a population of Cedrela fissilis Vell. (Meliaceae). MSc dissertation, Universidade de Campinas (UNICAMP), Campinas, SP, Brasil, 154 pp. (in Portuguese)

Ghazoul, J.; Mcleish, M. 2001. Reproductive ecology of tropical forest trees in logged and fragmented habitats in Thailand and Costa Rica. Plant Ecology, 153: 335-345.

Gribel, R.; Gibbs, P.E. ; Queiroz; A.L. 1999. Flowering phenology and pollination biology of Ceiba pentandra (Bombacaceae) in Central Amazonia. Journal of Tropical Ecology, 15: 247-263.

Hamrick, J.L.; Murawski, D.A. 1990. The breeding structure of tropical trees. Plant Species Biology, 5: 157-165.

Hubbell, S.P.; Foster, R.B. 1986. Commonness and rarity in a neotropical forest: implications for tropical tree conservation. 
In: Soulé, M.E. (Ed). Conservation biology: science of scarcity and diversity. Sinauer Associates, Sunderland, Massachusetts, p. 205-223.

Lepsch-Cunha, N.; Mori, S.A. 1999. Reproductive phenology and mating potential in a low density tree population of Couratari multiflora (Lecythidaceae) in central Amazonia. Journal of Tropical Ecology, 15: 97-121.

Lepsch-Cunha, N.; Gascon, C.; Kageyama, P.Y. 2001. The genetics of rare tropical trees: implications for conservation of a demographically heterogenous group. In: Bierregaard, R.O. Jr; Gascon, C.; Lovejoy, T.E.; Mesquita, R. (Eds.) Lessons from Amazonia: The Ecology and Conservation of a Fragmented Forest. Yale University Press, Chicago, p. 79-95.

Lepsch-Cunha, N.; Kageyama, P.Y.; Vencovsky, R. 1999. Genetic Diversity of Couratari multiflora and Couratari guianensis (Lecythidaceae): Consequences of Two Types of Rarity. Biodiversity and Conservation, 8: 1205-1218.

Mitchell, J.D.; Mori, S.A. 1987. Ecology. In: Mori, S.A.; Collaborators. The Lecythidaceae of a lowland neotropical forest: La Fumée Mountain, French Guiana. Memoirs of the New York Botanical Garden, 44: 137-155.

Mori, S.A.; Boeke, J. 1987. Pollination. In: Mori, S.A.; Collaborators The Lecythidaceae of a lowland neotropical forest: La Fumée Mountain, French Guiana. Memoirs of the New York Botanical Garden, 44: 122-137.

Mori, S.A.; Collaborators. 1987. The Lecythidaceae of a lowland neotropical forest: La Fumée Mountain, French Guiana. Memoirs of the New York Botanical Garden, 44: 1-190.

Mori, S.A.; Lepsch-Cunha, N. 1995. Lecythidaceae of a Central Amazonian moist forest. Memoirs of the New York Botanical Garden, 75:1-55.

Mori, S.A.; Orchard, J.E.; Prance, G.T. 1980. Intrafloral pollen differentiation in the New World Lecythidaceae. Science, 209: 400-403.

Mori, S.A.; Prance, G.T. 1990. Lecythidaceae - Part II. The zygomorphic-flowered New World Genera (Couropita, Corythophora, Berthollethia, Couratari, Eschweilera and Lecythis). Flora Neotropica, 21: 1-376.

Murawski, D.A. 1995. Reproductive biology and genetics of tropical trees from a canopy perspective. In: Lowman, M.D.; Nadkarni NM (Eds.) Forest Canopies. Academic Press, Boston, p. 457-493.

Murawski, D.A.; Hamrick, J.L. 1991. The effect of the density of flowering individuals on the mating systems of nine tropical tree species. Heredity, 67: 167-174.

Murawski, D.A.; Hamrick, J.L. 1992a. The mating system of Cavallinesia platanifolia under extremes of flowering-tree density: a test of predictions. Biotropica, 24: 99-101.

Murawski, D.A.; Hamrick, J.L. 1992b. Mating system and phenology of Ceiba pentandra (Bombacaceae) in Central Panama. Journal of Heredity, 83: 401-404.
Murawski, D.A.; Hamrick, J.L.; Hubbell, S.P.; Foster, R.B. 1990. Mating system of two bombacaceous trees of a neotropical moist forest. Oecologia, 82: 501-506.

Murphy, R.W.; Sites, J.W.; Buth, D.G.; Haufler, C.H. 1990. Proteins I: Isozyme Electrophoresis. In: Hillis, D.M.; Moritz, C. (Eds.). Molecular Systematics. Sinauer Associates, Inc Publishers, London, p. 373-409.

Oliveira, A.A.; Mori, S.A. 1999. A central Aamzonian terra firme forest. I. High tree species richness on poor soils. Biodiversity and Conservation, 8: 219-1244.

O'Malley, D.M.; Bawa, K.S. 1987. Mating system of a tropical rain forest tree species. American Journal of Botany, 74: 1143-49.

Nason, J.D.; Hamrick, J.L. 1997. Reproductive and genetic consequences of forest fragmentation: two case studies of Neotropical canopy trees. The Journal of Heredity, 88: 264-276.

Ritland, K. 1983. Estimation of mating systems. In: Tanksley, S.D.; Orton, T.J. (Eds.). Isozymes in plant genetics and breeding. Part A. Elsevier Publishers, Amsterdam, The Netherlands, p. 289-302.

Ritland, K. 1990. A series of FORTRAN computer programs for estimating plant mating systems. The Journal of Heredity, 81: 235-237.

Ritland, K.; El-Kassaby, Y.A. 1985. The nature of inbreeding in a seed orchard of Douglas fir as shown by efficient multilocus model. Theoretical Applied Genetics, 71: 375-384.

Ritland, K.; Jain, S. 1981. A model for the estimation of outcrossing rate and gene frequencies using $\mathrm{n}$ independent loci. Heredity, 47: 35-52.

Sebbenn, A.M.; Kageyama, P.Y.; Siqueira, A.C.M.F.; Zanatto, A.C.S. 2000. Mating system in populations of Cariniana legalis Mart. O. Ktze.: implications for genetic conservation and improvement. Scientia Forestalis, 58: 25-40 (in Portuguese).

Shaw, D.V.; Allard, R.W. 1981. Estimation of outcrossing rates in Douglas-fir using isozyme markers. Theoretical Applied Genetics, 62: 113-120.

Soltis, D.E.; Soltis, P.S. 1990. Isozymes in plant biology. Chapman and Hall, London, 233 pp.

Stacy, E.A.; Hamrick, J.L.; Nason, J.D.; Hubbell, S.P.; Foster, R.B.; Condit, R. 1996. Pollen dispersal in low-density populations of three neotropical tree species. The American Naturalist, 148: 275-298.

Swofford, D.L.; Selander, R.B. 1989. Byosys-1 A computer program for the analysis of allelic variation in population genetics and biochemical systematics. Release 1,7, Illinois Natural History Survey, Illinois.

Weeden, N.F.; Gottlieb, L.D. 1980. The genetics of chromoplast enzymes. The Journal of Heredity, 71: 392-396.

White, G.M.; Powell, W.; Boshier, D. 1998. The dynamics of pollen flow detected in a fragmented population of Swietenia 


\section{ACTA}

Outcrossing rate of Couratari multiflora (J.Smith)

AMAZONICA

humilis (Zucc.) using SSRs as a marker system. Abstract no. 183. American Journal of Botany, 85: S62.

Workman, P.; Niswander, J.L. 1970. Population studies on southwestern Indian tribes. II. Local genetic differentiation in the Papago. American Journal of Human Genetics, 22: 24-49.
Wright, S. 1965. The interpretation of population structure by F-statistics with special regard to systems of mating. Evolution, 19: 395-420..

Recebido em 28/02/2010

Aceito em 23/07/2010 
